\title{
Prevalence and factors associated with the need for removable prostheses in brazilian
}

\section{elderly}

Prevalência e fatores associados à necessidade de próteses removíveis em idosos brasileiros

Prevalencia y factores asociados a la necesidad de prótesis removibles en ancianos brasileños

\begin{abstract}
Objective: This study aimed to identify the prevalence and factors associated with the need for removable prostheses in the elderly Brazilian population. In addition, its impact on eating difficulties and self-perceived oral health was determined. Methodology: This cross-sectional, population-based study used data from the last National Health Survey (NHS) carried out in Brazil. Chi-square test was used to initially analyze the data, followed by multiple Poisson regression to obtain adjusted prevalence ratios. Results: A total of 11,697 elderly people were included, of whom $90.8 \%$ needed removable prostheses. Complete dentures were needed in $40.9 \%$ of participants, while partial dentures were needed by $49.9 \%$. The elderly who were older $(\mathrm{p}=0.001)$, had grayish-brown complexion $(\mathrm{p}=0.004)$, a low level of education $(p<0.001)$, and multiple chronic diseases $(p<0.001)$ had a greater need for removable prostheses. Successively, this need had an impact on poor self-perceived oral health $(p<0.001)$ and greater difficulties in eating $(\mathrm{p}<0.001)$. Conclusion: The need for a removable prosthesis is associated with worse socioeconomic and health conditions. In addition, it has a negative impact on self-perceived oral health and feeding.
\end{abstract}

Keywords: Removable prosthesis; Seniors; Prevalence; Associated factors.

\section{Resumo}

Objetivo: Este estudo objetivou identificar a prevalência e os fatores associados à necessidade de próteses removíveis em idosos. Ademais, verificou-se o impacto dessa necessidade na dificuldade de se alimentar e na autopercepção de 
saúde bucal. Metodologia: O presente estudo é caracterizado por ser do tipo seccional e de base populacional. Para a realização do mesmo, os dados da última Pesquisa Nacional de Saúde (PNS) realizada no Brasil foram utilizados. Na análise dos dados, o teste Qui-quadrado foi usado inicialmente. A posteriori, a regressão múltipla de Poisson foi utilizada e as razões de prevalências ajustadas foram obtidas. Resultados: A amostra foi composta por 11.697 idosos, dentre os quais $90,8 \%$ necessitavam de próteses removíveis. A necessidade de prótese total dupla foi de 40,9\%, enquanto a de prótese parcial removível foi de 49,9\%. O fato do idoso ser mais velho ( $\mathrm{p}=0,001$ ), de cor parda $(\mathrm{p}=0,004)$, não possuir instrução $(\mathrm{p}<0,001)$ e serem acometidos por mais de uma doença crônica $(\mathrm{p}<0,001)$ influenciaram em maiores necessidades de próteses removíveis. Por sua vez, essa necessidade impactou em uma autopercepção de saúde bucal ruim $(\mathrm{p}<0,001)$ e em maiores dificuldades de se alimentar ( $\mathrm{p}<0,001)$. Conclusão: Como conclusão, a necessidade de prótese removível está associada a piores condições socioeconômicas e de saúde. Além disso, essa necessidade impacta negativamente na autopercepção de saúde bucal e na alimentação.

Palavras-chave: Prótese removível; Idosos; Prevalência; Fatores associados.

\section{Resumen}

Objetivo: Este estudio tuvo como objetivo identificar la prevalencia y los factores asociados a la necesidad de prótesis removibles en ancianos. Además, se verificó el impacto de esta necesidad en la dificultad para comer y en la autopercepción de la salud bucal. Metodología: El presente estudio se caracteriza por ser seccional y poblacional. Para realizar lo mismo, se utilizaron datos de la última Encuesta Nacional de Salud (ENP) realizada en Brasil. En el análisis de datos se utilizó inicialmente la prueba de Chi-cuadrado. A posteriori se utilizó la regresión múltiple de Poisson y se obtuvieron las razones de prevalencia ajustadas. Resultados: La muestra estuvo constituida por 11.697 ancianos, de los cuales el 90,8\% necesitó dentadura postiza removible. La necesidad de dentaduras postizas dobles fue del 40,9\%, mientras que la necesidad de dentaduras postizas parciales removibles fue del 49,9\%. El hecho de que los ancianos fueran mayores $(\mathrm{p}=0,001)$, morenos $(\mathrm{p}=0,004)$, sin educación $(\mathrm{p}<0,001)$ y afectados por más de una enfermedad crónica ( $\mathrm{p}<0,001)$ influyó en una mayor necesidad de prótesis removibles. Esta necesidad, a su vez, incidió en la autopercepción de mala salud bucal ( $\mathrm{p}<0,001)$ y mayores dificultades para comer $(\mathrm{p}<0,001)$. Conclusión: En conclusión, la necesidad de prótesis removibles se asocia a peores condiciones socioeconómicas y de salud. Además, esta necesidad tiene un impacto negativo en la autopercepción de la salud bucal y la nutrición.

Palabras clave: Prótesis removible; Personas mayores; Predominio; Factores asociados.

\section{Introduction}

The elderly population has been rapidly increasing worldwide due to reduced fertility rate, increased life expectancy, and lower mortality rates (Beard et al., 2016). This demographic transition is accompanied by an increase in the demand for health services, including dental care (Melo et al., 2020; Colussi et al., 2002). Thus, suitable adjustments to meet the treatment needs of this population are necessary in the provision of oral health services (Colussi et al., 2002).

In the elderly, the main oral characteristics are partial and total tooth loss. Globally, the total edentulism rate is $2.3 \%$ and this condition is strongly associated with unfavorable socioeconomic conditions (Yellowitz et al., 2014; Seerig et al., 2015). The consequences of tooth loss include impaired chewing, digestion, phonation, and poor aesthetic (Azevedo et al., 2015; Azevedo et al., 2017). In addition, some individuals have psychological disorders and experience negative impact on quality of life (Azevedo et al., 2015; Azevedo et al., 2017). Owing to these sequelae, partial or total loss of dental elements is considered a public health problem (Azevedo et al., 2017). A viable solution is rehabilitation with removable prostheses. The conventional complete and removable partial dentures can improve the quality of life, when technically sound (Medeiros et al., 2019; Barreto et al., 2015).

The need for dental prostheses, in most studies, is investigated based on indices developed by the World Health Organization (WHO), considering tooth loss in the upper and/or lower arches. For the year 2000, the WHO set the goal of 20 or more teeth in the mouth of at least $50 \%$ of the elderly population aged between 65 and 74 years (FDI, 1982). However, data from some countries reveal that they are far from reaching this goal. In Brazil, the last nationwide epidemiological survey of oral health (National Survey of Oral Health - SBBrasil 2010), found only $11.5 \%$ of the elderly in this age group with 20 or more teeth (Peres et al., 2013). Considering these data, the oral rehabilitation services should be increased, especially for the elderly population. 
In this context, using current data to identify the need for removable dentures and the factors influencing it may assist in the implementation of public policies to minimize tooth loss and its functional, aesthetic, psychological, and social consequences. Thus, the aim of this study was to identify the prevalence and factors associated with the need for removable prostheses in the elderly. In addition, the impact of the necessity of removable dentures on eating and self-perceived oral health was verified.

\section{Methodology}

\section{Study design and location}

The present study was characterized by being sectional and population-based, with the elderly as the object of research. The secondary data from the last National Health Survey (NHS) carried out in Brazil was used. This study was approved by the National Research Ethics Commission in 2013 (approval no. 328.159).

\section{Participants}

Data from the NHS represent the Brazilian population aged over 18 years residing in both rural and urban areas of the five macro-regions of Brazil. However, for inclusion, only elderly people aged 60 years or older were included in this study; a total of 11,697 participants were identified. This sample was representative of the Brazilian population over 60 years old, with verification of the sample calculation using the NHS methodology (Szwarcwald et al., 2014).

\section{Need for removable dentures}

To identify individuals who needed removable dentures (complete and/or partial), the elderly had to report partial and/or total loss of teeth in the upper and/or lower arches. The following questions were asked, "Did you lose any top teeth?" and "Did you lose any teeth from below?". As an answer, the possibilities were: "No"; "Yes I lost xx elements", where "xx" represented the amount of elements lost and "Yes, I lost all dental elements".

\section{Independent variables}

A total of three groups of independent variables were analyzed, including socioeconomic conditions, lifestyle, and general health. Within the group of socioeconomic variables, the following were considered: sex, age, racial classification, marital status, education, and health and dental plans. The factors that represented lifestyle were tobacco use, alcoholic beverage intake, and toothbrushing frequency; general health was represented by multimorbidity (presence of two or more chronic diseases in the same individual). The studied variables possibly affected by the need for removable prosthesis included difficulty in eating and self-perception of oral health. All variables were collected from the NHS questionnaire.

\section{Statistical analysis}

SPSS version 20.0, was used to analyze the study data. For the construction of the tables, frequency distribution of all research variables was performed. To verify the association between the need for a removable prosthesis with the groups of independent variables studied and those representing the impact of this necessity, chi-square test was used with a 95\% confidence level. Using the results of this first analysis, the variables that obtained a value of $\mathrm{p}<0.200$ were subjected to chisquare test to verify multicollinearity. Variables were considered multicollinear when a $p$ value $\leq 0.05$ was obtained, and those strongly associated with each other were not included in the adjustment model. To complete the analysis, Poisson multiple regression was used to identify adjusted prevalence ratios. In all tests, data were weighted considering the effect of the sampling plan, non-response rates, and post-stratification weights. A 95\% confidence level was also used in the Poisson multiple regression. 


\section{Results}

A total of 11,697 elderly people were included in the study with an average age of 70.1 years $( \pm 0.1)$, with ages ranging from 60 to 107 years. Majority of elderly Brazilians were characterized as being younger (aged between 60 and 69 years [55.2\%]), female (60\%), married $(44.5 \%)$, white $(54.7 \%)$, with incomplete elementary education $(38.4 \%)$, and lacked a dental or health plan $(92.2 \%$ and $68.3 \%$, respectively). Most participants did not smoke or consume alcoholic beverages (84.7\% and $73.6 \%$, respectively), and practiced oral hygiene at least once a day (96.8\%). Most participants had multimorbidity $(53.1 \%)$, had no difficulty in eating due to problems related to teeth $(96.5 \%)$, and reported good or very good oral health conditions $(63.2 \%)$. The prevalence of partial or total loss of teeth and, consequently, the need for removable dentures was $90.8 \%$, of which $40.9 \%$ needed complete dentures and $49.9 \%$, partial ones.

Frequency of independent variables according to the need for removable prosthesis, as well as their associations on univariate analysis, are shown in Table 1.

Table 1. Association between the need for removable prosthesis in the elderly with socioeconomic, general health and lifestyle variables.

\begin{tabular}{|c|c|c|c|c|c|c|}
\hline & & $\begin{array}{c}\text { With need of } \\
\text { removable prosthesis }\end{array}$ & $\begin{array}{c}\text { No need for } \\
\text { removable prosthesis }\end{array}$ & & & \\
\hline Variable & Category & $\%$ & $\%$ & PR & CI 95\% & $p$ \\
\hline \multirow{2}{*}{ Gender } & Female & 91.8 & 8.2 & 1.31 & $1.08-1.59$ & .005 \\
\hline & Male & 89.3 & 10.7 & & & \\
\hline \multirow{3}{*}{ Age } & 60 to 69 years & 89.9 & 10.1 & 1.00 & & .004 \\
\hline & 70 to 79 years & 90.1 & 9.9 & 1.01 & $.98-1.03$ & \\
\hline & 80 years or more & 92.9 & 7.1 & 1.03 & $1.01-1.05$ & \\
\hline \multirow{4}{*}{ Racial classification } & White & 89.3 & 10.7 & 1.00 & & $<.001$ \\
\hline & Grayish-brown & 92.7 & 7.3 & 1.04 & $1.02-1.06$ & \\
\hline & Black & 92.1 & 7.9 & 1.03 & $1.00-1.06$ & \\
\hline & Others & 91.7 & 8.3 & 1.03 & $.97-1.08$ & \\
\hline \multirow{4}{*}{ Marital status } & Divorced & 88.1 & 11.9 & 1.00 & & .033 \\
\hline & Married & 90.2 & 9.8 & 1.02 & $.99-1.06$ & \\
\hline & Single & 91.7 & 8.3 & 1.02 & $1.00-1.05$ & \\
\hline & Widower & 92.0 & 8.0 & 1.05 & $1.01-1.08$ & \\
\hline \multirow{3}{*}{ Education } & $\begin{array}{l}\text { Complete elementary } \\
\text { school or more }\end{array}$ & 86.0 & 14.0 & 1.00 & & $<.001$ \\
\hline & $\begin{array}{l}\text { Incomplete elementary } \\
\text { school }\end{array}$ & 92.8 & 7.2 & 1.96 & $1.58-2.42$ & \\
\hline & Without instruction & 92.9 & 7.1 & 1.97 & $1.61-2.41$ & \\
\hline \multirow{2}{*}{ Health plan } & No & 91.1 & 8.9 & 1.02 & $.99-1,04$ & .160 \\
\hline & Yes & 89.7 & 10.3 & & & \\
\hline \multirow{2}{*}{ Smoking } & Yes & 74.4 & 25.6 & 0.79 & $0.76-0.83$ & $<.001$ \\
\hline & No & 93.8 & 6.2 & & & \\
\hline \multirow{2}{*}{ Use of alcoholic drink } & Yes & 92.1 & 7.9 & 1.02 & $1.00-1.04$ & .140 \\
\hline & No & 90.4 & 9.6 & & & \\
\hline \multirow{2}{*}{ Multimorbidity } & Yes & 95.2 & 4.8 & 1.03 & $1.01-1.05$ & $<.001$ \\
\hline & No & 92.5 & 7.5 & & & \\
\hline \multirow{2}{*}{ Brushing frequency } & Do not brush every day & 96.5 & 3.5 & 1.03 & $1.00-1.07$ & .097 \\
\hline & At least once a day & 93.3 & 6.7 & & & \\
\hline \multirow{2}{*}{ Dental plan } & No & 89.6 & 10.4 & 1.03 & $.95-1.12$ & .404 \\
\hline & Yes & 86.9 & 13.1 & & & \\
\hline
\end{tabular}


PR: Prevalence Ratio; CI: Confidence Interval. Source: Authors.

The results of this analysis showed the variable "smoking" to be strongly associated with other independent variables. Therefore, it was not included in the adjustment of multivariate analysis. On multivariate analysis, it was found that the elderly person who was older, grayish-brown in color, without any education, and with multimorbidity had greater need for removable prostheses (Table 2).

Table 2. Association between the need for removable prosthesis in the elderly with socioeconomic, general health and lifestyle variables with their adjusted gross prevalence ratio measures.

\begin{tabular}{|c|c|c|c|c|c|c|}
\hline & & $\begin{array}{l}\text { With need of } \\
\text { removable } \\
\text { prosthesis }\end{array}$ & $\begin{array}{l}\text { No need for } \\
\text { removable } \\
\text { prosthesis }\end{array}$ & & & \\
\hline Variable & Category & $\%$ & $\%$ & $\mathrm{PR}_{\mathrm{AJ}}$ & $\mathrm{CI}_{\mathrm{AJ}} 95 \%$ & $p^{*}$ \\
\hline \multirow{2}{*}{ Gender } & Female & 91.8 & 8.2 & 1.07 & $1.03-1.11$ & .738 \\
\hline & Male & 89.3 & 10.7 & & & \\
\hline \multirow{3}{*}{ Age } & 60 to 69 years & 89.9 & 10.1 & 1.00 & & .001 \\
\hline & 70 to 79 years & 90.1 & 9.9 & 1.01 & $1.00-1.02$ & \\
\hline & 80 years or more & 92.9 & 7.1 & 1.05 & $1.02-1.07$ & \\
\hline \multirow{4}{*}{$\begin{array}{c}\text { Racial } \\
\text { classification }\end{array}$} & White & 89.3 & 10.7 & 1.00 & & .004 \\
\hline & Grayish-brown & 92.7 & 7.3 & 1.03 & $1.01-1.05$ & \\
\hline & Black & 92.1 & 7.9 & 1.03 & $1.00-1.07$ & \\
\hline & Others & 91.7 & 8.3 & 1.01 & $.95-1.06$ & \\
\hline \multirow{4}{*}{ Marital status } & Divorced & 88.1 & 11.9 & 1.00 & & .877 \\
\hline & Married & 90.2 & 9.8 & 1.01 & $.95-1.03$ & \\
\hline & Single & 91.7 & 8.3 & 1.01 & $.98-1,04$ & \\
\hline & Widower & 92.0 & 8.0 & 1.03 & $1.00-1.07$ & \\
\hline \multirow{4}{*}{ Education } & $\begin{array}{l}\text { Complete elementary } \\
\text { school or more }\end{array}$ & 86.0 & 14.0 & 1.00 & & $<.001$ \\
\hline & & & & & & \\
\hline & $\begin{array}{l}\text { Incomplete elementary } \\
\text { school }\end{array}$ & 92.8 & 7.2 & 1.93 & $1.43-2.31$ & \\
\hline & Without instruction & 92.9 & 7.1 & 1.95 & $1.55-2.33$ & \\
\hline \multirow{2}{*}{ Multimorbidity } & Yes & 95.2 & 4.8 & 1.02 & $1.01-1.03$ & $<.001$ \\
\hline & No & 92.5 & 7.5 & & & \\
\hline
\end{tabular}

p*: p-value adjusted from the multiple Poisson regression. PR: Prevalence Ratio; CI: Confidence Interval. Source: Authors.

It was observed that this need had an impact on poor to very poor oral health self-perception and on an intense to very intense difficulty in eating on both univariate (Table 3) and multivariate analysis (Table 4). 
Table 3. Association between the need for removable prosthesis and the independent variables analyzed that represent its impact.

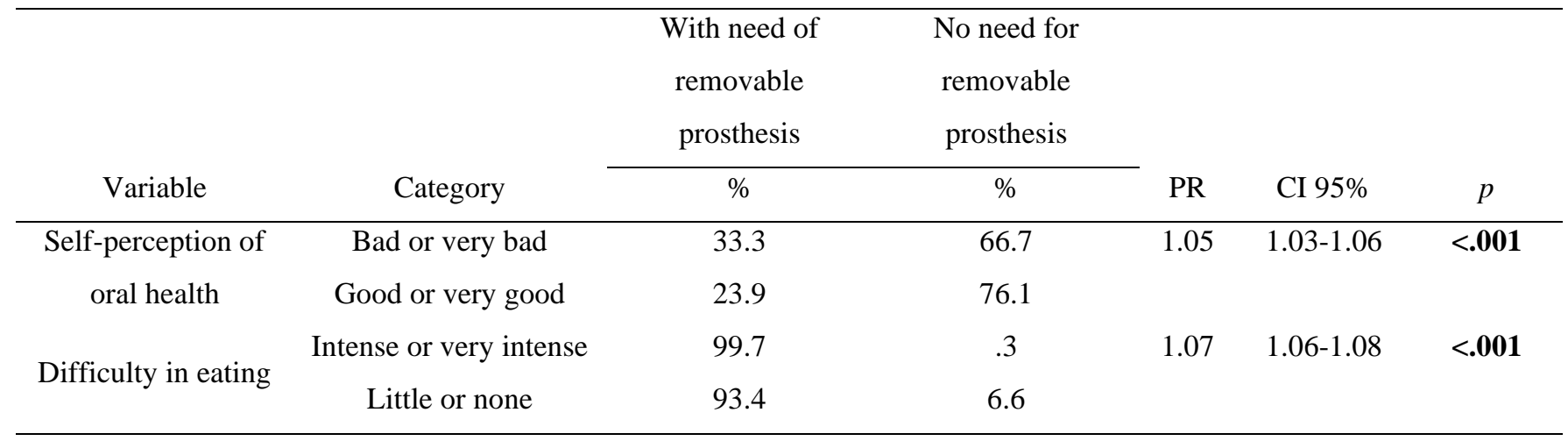

PR: Prevalence Ratio; CI: Confidence Interval. Source: Authors.

Table 4. Association between the need for removable prosthesis and the independent variables analyzed that represent its impact with its adjusted gross prevalence ratio measures.

\begin{tabular}{|c|c|c|c|c|c|c|}
\hline & & $\begin{array}{l}\text { With need of } \\
\text { removable } \\
\text { prosthesis }\end{array}$ & $\begin{array}{l}\text { No need for } \\
\text { removable } \\
\text { prosthesis }\end{array}$ & & & \\
\hline Variável & Categoria & $\%$ & $\%$ & $\mathrm{PR}_{\mathrm{AJ}}$ & $\mathrm{CI}_{\mathrm{AJ}} 95 \%$ & $p^{*}$ \\
\hline Self-perception of & Bad or very bad & 33.3 & 66.7 & 1.03 & $1.02-1.04$ & $<.001$ \\
\hline oral health & Good or very good & 23.9 & 76.1 & & & \\
\hline \multirow{2}{*}{ Difficulty in eating } & Intense or very intense & 99.7 & .3 & 1.02 & $1.01-1.03$ & $<.001$ \\
\hline & Little or none & 93.4 & 6.6 & & & \\
\hline
\end{tabular}

p*: p-value adjusted from the multiple Poisson regression. PR: Prevalence Ratio; CI: Confidence Interval. Source: Authors.

\section{Discussion}

The present study aimed to identify the prevalence of the need for removable prostheses in the elderly and the factors influencing it. In addition, it was verified whether the need for removable dentures impacts difficulty of eating and selfperception of oral health. The results of this study are representative of the entire elderly Brazilian population. In view of its negative impact on quality of life, damage to chewing, swallowing, phonation, aesthetics, and psychological disorders, tooth loss is considered a public health problem. Identifying its prevalence, associated factors, and its impact is of great value for the establishment of measures aimed at preventing this disease (Azevedo et al., 2015; Azevedo et al., 2017).

The prevalence of the need for removable dentures in Brazilian elderly population was $90.8 \%$, consistent with the last oral health survey conducted in Brazil in 2010, where prevalence was 92.7\% (Peres et al., 2013). This fact shows minimal reduction, reflecting an invasive dental practice still focused on dental extractions. Given a frequency above $90 \%$, partial or total loss of dental elements was present in almost the entire study population. This shows that the dental services to be prioritized must focus on the oral rehabilitation of these elderly people, due to the serious consequences of edentulism discussed in the Introduction. About $40.9 \%$ of elderly Brazilians were totally edentulous. This figure is different in developed countries, with only $16 \%$ of elderly people in France and Norway being edentulous (Azevedo et al., 2017). Therefore, tooth loss is strongly influenced by the country's level of development and socioeconomic condition. 
In this study, it was found that the elderly people who were older, grayish-brown in complexion, with no education, and with multimorbidity had a greater requirement of removable prostheses. As elderly individuals suffer accentuated physiological aging, they have other health concerns that they may prioritize over oral health (DuGoff et al., 2014). In addition, many elderly people end up losing their functional capacity, and oral hygiene becomes the responsibility of caregivers, who are sometimes untrained or do not perform it with adequate frequency. As a consequence, tooth loss can occur through the progression of periodontal disease. Another explanation for this association is related to the cumulative effect related to oral diseases, such as dental caries and periodontal diseases in the elderly (Ren et al., 2017).

Within the context of the color/race of the elderly, the literature reports grayish-brown or black complexion individuals having worse general health and socioeconomic status (Oliveira et al., 2014). When comparing elderly with white complexion with those grayish-brown or black, the latter were revealed to have high dependence on public health services, less education, lower income, and worse health indicators (Oliveira et al., 2014; Clarke et al., 2011). Thus, this population most likely has greater difficulties in accessing health services to prevent tooth loss, either economically or due to prioritizing other health treatments. With regard to low education as a factor associated with the need for removable dentures, uneducated individuals are less empowered to seek knowledge on treatment and prevention of dental element loss, whether partial or total. Thus, the elderly without education probably have worse oral health behaviors (Ren et al., 2017). In accordance with other studies, the accumulation of chronic diseases in this present study was associated with the need for dental prostheses (Felton et al., 2016; Liljestrand et al., 2015). This can be explained by the greater physical disability and functional decline in these elderly people. These characteristics can cause difficulties in accessing dental care services and in performing oral hygiene practices. As a consequence, the elderly become more susceptible to dental caries, periodontal diseases, and tooth loss (Ren et al., 2017; Okoro et al., 2012).

As for the impact caused by partial or total loss of dental elements, it was observed that elderly Brazilians who had tooth loss had greater difficulties in eating, consistent with the previous studies (Azevedo et al., 2015; Azevedo et al., 2017; Shao et al., 2018). The main functions of dental elements are apprehension and crushing of food, reducing its size, and enabling formation of the bolus for deglutition functions which are impaired in the presence of eduntulism Tada et al., 2014; Choi et al., 2016). Thus, elderly people may become more prone to malnutrition due to low chewing capacity and altered diet (usually individuals with tooth loss have a diet high in fat and low in fiber and vitamins). In addition, as a result of malnutrition, the elderly can be affected by systemic diseases such as cardiovascular diseases and diabetes (Felton et al., 2016). Therefore, preservation of teeth is essential. Thus, it is necessary to change dental mutilation practices by instituting measures aimed at preventing tooth loss in the elderly population. These are essential for maintaining masticatory capacity and, consequently, improving general health.

Even after adjusting for other variables, it was observed that the need for removable prostheses reflected a greater chance of the elderly reporting a negative self-perception of oral health. It is suggested that due to negative impact on chewing capacity which can also result in a possible shift to a soft diet, the elderly who have tooth loss tend to report poor oral health quality. This poor self-perception of oral health is generally related to a low quality of life. Thus, rehabilitation with removable prostheses can contribute to an improvement in not just in masticatory capacity but also a better quality of life (Medeiros et al., 2019; Barreto et al., 2015).

As this is a cross-sectional study, it is not possible to establish exact causation between the analyzed variables. However, this large, population-based study can present generalizable data for countries with social, cultural, and economic conditions similar to Brazil regarding factors influencing tooth loss. From the results of this study, greater attention should be given to the prevention of tooth loss in the elderly with unfavorable socioeconomic conditions having multimorbidity. In view 
of the great number of elderly people who have lost their teeth, rehabilitative dental services for these individuals should be prioritized. This can help restore chewing capacity and provide better quality of life for this population.

\section{Conclusion}

According to the results obtained, the need for removable prostheses is associated with worse socioeconomic conditions and general health status in the elderly. Furthermore, this need in the elderly Brazilians negatively impacts selfperceived oral health and causes chewing difficulties.

As this is a cross-sectional study, it is not possible to establish exact causation between the analyzed variables. In this sense, it is recommended to carry out longitudinal studies on the subject.

\section{References}

Azevedo, J. S., Azevedo, M. S., Oliveira, L. J. C. \& Demarco, F. F. (2017). Needs for dental prostheses and their use in elderly Brazilians according to the National Oral Health Survey (SBBrazil 2010): prevalence rates and associated factors. Cad Saúde Pública, 33 (8), e00054016.

Azevedo, M. S., Correa, M. B., Azevedo, J. S. \& Demarco, F. F. (2015). Dental prosthesis use and/or need impacting the oral health-related quality of life in Brazilian adults and elders: results from a national survey. J Dent, 43 (12), 1436-1441.

Barreto, A. O., Aquino, L. M. M., Aquino, A. R. L., Roncalli, A. G., Amaral, B. A. \& Carreiro, A. F. P. (2015). Impact on quality of life of removable partial denture wearers after 2 years of use. Braz, J Oral Sci, 10 (1), 50-54.

Beard, J. R., Officer, A. M. \& Cassels, A. K. (2016). The World Report on Ageing and Health. Gerontologist, 56 (Suppl 2), $163-166$.

Choi, S. H., Kim, J. S., Cha, J. Y., Lee, K. J., Yu, H. S. \& Hwang, C. J. Subjective food intake ability related to oral health-related quality of life and psychological health. J Oral Rehabil, 43 (9), 670-677.

Clarke, P. \& Smith, J. (2011). Aging in a cultural context: cross- national differences in disability and the moderating role of personal control among older adults in the United States and England. J Gerontol B Psychol Sci Soc Sci, 66 (4), 457-67.

Colussi, C. F. \& Freitas, S. F. (2002). Epidemiological aspects of oral health among the elderly in Brazil. Cad Saúde Pública, 18 (5), $1313-1320$.

DuGoff, E. H., Canudas-Romo, V., Buttorff, C., Leff, B. \& Anderson, G. F. (2014). Multiple Chronic Conditions and Life Expectancy: A Life Table Analysis. Med Care, 52 (8), 688-694.

FDI. (1982) Global goals for oral health in the year 2000. Int Dent J, 32 (1), 74-77.

Felton, D. A. (2016). Complete edentulism and comorbid diseases: an update. J Prosthodont, 25 (1), 5-20.

Liljestrand, J. M., Havulinna, A. S., Paju, S., Männistö, S., Salomaa, V. \& Pussinen P. J. (2015). Missing teeth predict incident cardiovascular events, diabetes, and death. J Dent Res, 94 (8), 1055-1062.

Medeiros, A. K. B., Campos, M. F. T. P., Costa, R. S. G. S., Melo, L. A., Barbosa, G. A. S. \& Carreiro, A. F. P. (2019). Improvement in quality of life of elderly edentulous participants with new complete dentures: a systematic review. Int J Prosthodont, 32 (3), 272-277.

Melo, L. A. \& Lima K. C (2020). Prevalence and associated factors with multimorbities in elderly brazilians. Cien Saúde Colet, 25 (10), $3869-3877$.

Okoro, C. A., Strine, T. W., Eke, P. I., Dhingra, S. S. \& Balluz, L. S. (2012). The association between depression and anxiety and use of oral health services and tooth loss. Community Dent Oral Epidemiol, 40 (2), 134-144.

Oliveira, B. L. C. A, Thomaz, E. B. A. F. \& Silva, R. A. (2014). The association between skin color/race and health indicators in elderly Brazilians: a study based on the Brazilian National Household Sample Survey (2008). Cad Saúde Pública, 30 (7), 1438-1452.

Peres, M. A., Barbato, P. R., Reis, S. C., Freitas, C. H. \& Antunes, J. L. (2013). Tooth loss in Brazil: analysis of the 2010 Brazilian Oral Health Survey. Rev Saúde Pública, 47 (Suppl 3), 78-89.

Ren, C., McGrath, C. \& Yang, Y. (2017). Edentulism and associated factors among community-dwelling middle-aged and elderly adults in China. Gerodontology, 34 (2), 195-207.

Seerig, L. M., Nascimento, G. G., Peres, M. A., Horta, B. L. \& Demarco, F. F. (2015). Tooth loss in adults and in- come: systematic review and meta-analysis. J Dent, 43: (9), 1051-1059.

Shao, Z., Guo, X., Zhang, Q., Bronkhorst, E. M., Zou, D. \& Creugers, N. H. J. (2018). Masticatory efficiency in patients with partially dentate dentitions. J Dent, 75 (1), 41-47.

Szwarcwald, C. L., Malta, D. C., Pereira, C. A, et al. (2014). National Health Survey in Brazil: design and methodology of application. Cien Saude Colet, 19 (2), 333-342. 
Research, Society and Development, v. 10, n. 12, e499101220796, 2021

(CC BY 4.0) | ISSN 2525-3409 | DOI: http://dx.doi.org/10.33448/rsd-v10i12.20796

Tada, A. \& Miura, H. (2014). Systematic review of the association of mastication with food and nutrient intake in the independent elderly. Arch Gerontol Geriatr, 59 (3), 497-505.

Yellowitz, J. A. \& Schneiderman, M. T. (2014). Elder's oral health crisis. J Evid Based Dent Pract,14 (Suppl 14), 191-200. 